\title{
EXTRACTION AND CHARACTERIZATION OF OIL FROM NEEM AND YELLOW OLEANDER SEEDS FOR BIODIESEL PRODUCTION
}

\author{
Abdullahi Madu YAMI $^{1 *}$, Mohammed E. IBRAHIM ${ }^{1}$, Abdulkabir RAJI $^{1}$ \\ ${ }^{1}$ Department of Mechanical Engineering, Modibbo Adama University of Technology P.M.B 0274, Yola, Nigeria.
}

\begin{abstract}
Oil from neem and yellow oleander seeds were extracted using Soxhlet extractor with normal hexane as solvent and characterized using standard methods and their Physico chemical properties determined. The results revealed that the oil yields of neem and yellow oleander seeds are $38.80 \%$ and $49.69 \%$ respectively. Both oil samples contain high free fatty acid values, $8.77 \%$ for neem and $7.21 \%$ for yellow oleander. The characterization revealed the following results for neem seed oil; saponification value $=185.50 \mathrm{mg} \mathrm{KOH} / \mathrm{g}$, acid value $=17.54 \mathrm{mg}$ $\mathrm{KOH} / \mathrm{g}$, iodine value $=58 \mathrm{mg} \mathrm{I} / 100 \mathrm{~g}$, peroxide value $=7.95 \mathrm{mg} /$ peroxide $/ \mathrm{kg}$, viscosity at $40^{\circ} \mathrm{C}$ $=37.80 \mathrm{~mm} / \mathrm{s}^{2}$, specific gravity $=0.87$, and refractive index $=1.469$ while saponification value $=196.30 \mathrm{mg} \mathrm{KOH} / \mathrm{g}$, acid value $=14.42 \mathrm{mg} \mathrm{KOH} / \mathrm{g}$, iodine value $=81 \mathrm{mg} \mathrm{I} / 100 \mathrm{~g}$, peroxide value $=4.20 \mathrm{mg} /$ peroxide $/ \mathrm{kg}$, viscosity at $40{ }^{\circ} \mathrm{C}=31.40 \mathrm{~mm} / \mathrm{s}^{2}$, specific gravity $=0.96$, and refractive index $=1.467$ for yellow oleander seed oil. The results of the experimental analyses carried out in this study indicate that neem and yellow oleander seeds are high-yielding and good sources of oil for commercial biodiesel production. Values obtained for physico chemical properties of the extracted oils fall within the acceptable limits for oils suitable for biodiesel production by international standards. High free fatty values obtained revealed that the oils must undergo acid esterification before transesterification to avoid the formation of soap.
\end{abstract}

Keywords: Biodiesel, seed oil, Soxhlet Extractor, n-hexane, Free fatty acid, iodine value, saponification, value

\section{Introduction}

It has now been well established all over the world that vegetable seed oil can be a good feedstock for the production of renewable diesel fuel for diesel engines. Due to the dwindling fossil fuel sources and pollution arising from fossil fuel combustion, there is a significant progress in the research and consequently increase in demand for vegetable fats for the production of biofuels, especially biodiesel for automotive and transport. The term biofuel defines liquid or gaseous fuel produced primarily from biomass and intended for the transport sector. Currently, two types of biofuels are produced on a world scale that is bioethanol and biodiesel [1]. Bioethanol is an anhydrous ethyl alcohol obtained on a large scale by alcoholic fermentation of sugar from sugar beets, sugarcane, corn, wheat, straw or wood. At present, bioethanol is used in car engines as a maximum of $15 \%$ additive to gasoline [1,2]. Biodiesel (Greek, bio, life + diesel from Rudolf Diesel) is defined as a mixture of mono alkyl esters of long chain fatty acids (FA) derived from renewable lipids such as vegetable oils and animal fats when reacted with an alcohol (methanol or ethanol) in presence or absence of catalyst $[3,4,5,6]$. It was reported that biodiesel has similar fuel properties to diesel and therefore, can be used as a substitute for diesel fuel, either in neat form or in blends with petroleum diesel [6]. The idea of using vegetable oils began when Dr Rudolph Diesel, who invented the engine that was named after him, in 1895 with aim of using different fuels, including vegetable oil to power it [7]. Diesel tested "his" engine on peanut oil at the 1900 world's fair in Paris, the Exposition Universalle [8]. However full exploration of 
biodiesel became well established in the 1980s because of the rekindled interest in renewable energy sources as remedy to greenhouse gas (GHG) emission from fossil fuels and to compensate for shortages due to depletion of fossil fuel reserves [9]. Unlike fossil fuel diesel, biodiesel produces no sulphur, less carbon monoxide, less particulate matters, less soot and hydrocarbon emissions and contains more oxygen in its structure. The excess free oxygen leads to complete combustion and less emission $[9,10]$

According to [11], currently edible resources constitute $95 \%$ of biodiesel production feedstock. However, continuous and large scale production of biodiesel from edible oils has recently been of great concern because they compete with food materials- the food versus fuel dispute. There are concerns that biodiesel feedstock may compete with food supply in the long run. According to [12] the use of edible oil for biodiesel production was highest between 2004 and 2007.The production of biodiesel from edible vegetable oils such as those from soybeans, palm oil, sunflower, safflower, rapeseed, coconut and peanut may cause significant problems such as hunger especially in third world countries leading to upheavals [13]. According to United Nations Food and Agricultural Organization (FAO), 10\% of the recent food price increases around the world are as a result of the use of edible seed oils for biodiesel production [14]. Non edible seed oils have been found to be promising crude oils for the production of biodiesel. The use of non-edible oils when compared with edible oils in developing countries removes the pressure arising from their high demand make them costly to be used as diesel fuel.

The first important step in the production of biodiesel from plant seed oils is oil extraction. This study attempts to extract oil from two non-edible vegetable seeds of neem and yellow oleander, determining the physico chemical properties of the oil and comparing them with standard oil properties required for the production of high quality biodiesel fuel.

\section{Materials and Methods}

Fresh yellow oleander (Thevetia Peruviana) fruits were obtained from Shaffa in Hawul local Government Area of Borno State and Makera in Hong local Government Area of Adamawa State while neem seeds were obtained from Neem trees in Girei Town and its surroundings in Girei local Government Area of Adamawa State, Nigeria. The seeds were transported to the process center (Microbiology Department, Modibbo Adama University of Technology, Yola, Nigeria) and manually separated to remove all foreign matter and immature seeds. The clean seeds were kept at atmospheric temperature for three days which soften the mesocarp thereby making the removal of the kernels easy. The seeds were de-hulled to remove the seed-coat and husk manually using hard objects. The kernels from the fruits were then ground into pastes using pestle and mortar.

The chemical oil extraction method in which Soxhlet apparatus and n-hexane as solvent was used for the extraction of oil in this study. A $500 \mathrm{~g}$ mass of oil was weighed and $150 \mathrm{ml}$ of the solvent measured. The extractor was connected to glass tube in the middle, then to a condenser above it and then placed on heating mantle set at $50{ }^{\circ} \mathrm{C}$. After 1 hour, the middle glass tube was disconnected and the round bottom flask containing the solvent, oil and the sample was removed and then allowed to cool to room temperature and filtered to separate the residue. Filtrate, solvent and oil were placed in a beaker for the solvent to evaporate by exposing it to atmosphere to save time instead of recovering the solvent. The whole process was repeated for another constant mass of $500 \mathrm{~g}$ until the complete extraction was effected. The pure oil obtained was removed and dried on a hot plate set at $100^{\circ} \mathrm{C}$ for 15 minutes to remove some of the solvent left in the oil. Fig. 1 shows the set up for oil extraction using Soxhlet extractor.

The procedures used in the characterization of the crude oils were adapted from $[15,16]$ which are the American Oil Analytical Chemists' (AOAC) methods [17]. Each experiment repeated three times and averaged. 


\section{Determination of oil yield}

The weight of an empty dried beaker was measured as $\mathrm{W}_{1}$. The extracted oil was then poured in the beaker and the beaker and its content weighed as $\mathrm{W}_{2}$.

Weight of oil + beaker $=\mathrm{W}_{2}$, Weight of beaker $=\mathrm{W}_{1}$, Weight of seed paste $=\mathrm{W}_{3}$

The oil percentage was calculated using equation (1):

$$
\% \text { Oil yield }=\frac{\text { Weight of oil extracted }}{\text { Weight of Seed paste }} \times 100
$$

The same procedure was repeated to determine the oil yield for yellow oleander oil.

\section{Determination of acid value}

A mass $10 \mathrm{~g}$ seed oil was put into a conical flask and $50 \mathrm{ml}$ alcohol ether mixture was added. The mixture was then warmed until homogeneity was attained. This was then titrated against $0.1 \mathrm{M} \mathrm{NaOH}$ with phenolphthalein indicator with consistent shaking. The titration was stopped when the pink end point was attained

The acid value of the extracted oils were calculated using equation (2).

$$
\text { Acid value }=2 \times F F A
$$

The value of FFA obtained was used to ascertain as to whether they are within international standards of oils for biodiesel production and to determine the necessity or otherwise of the acid esterification stage.

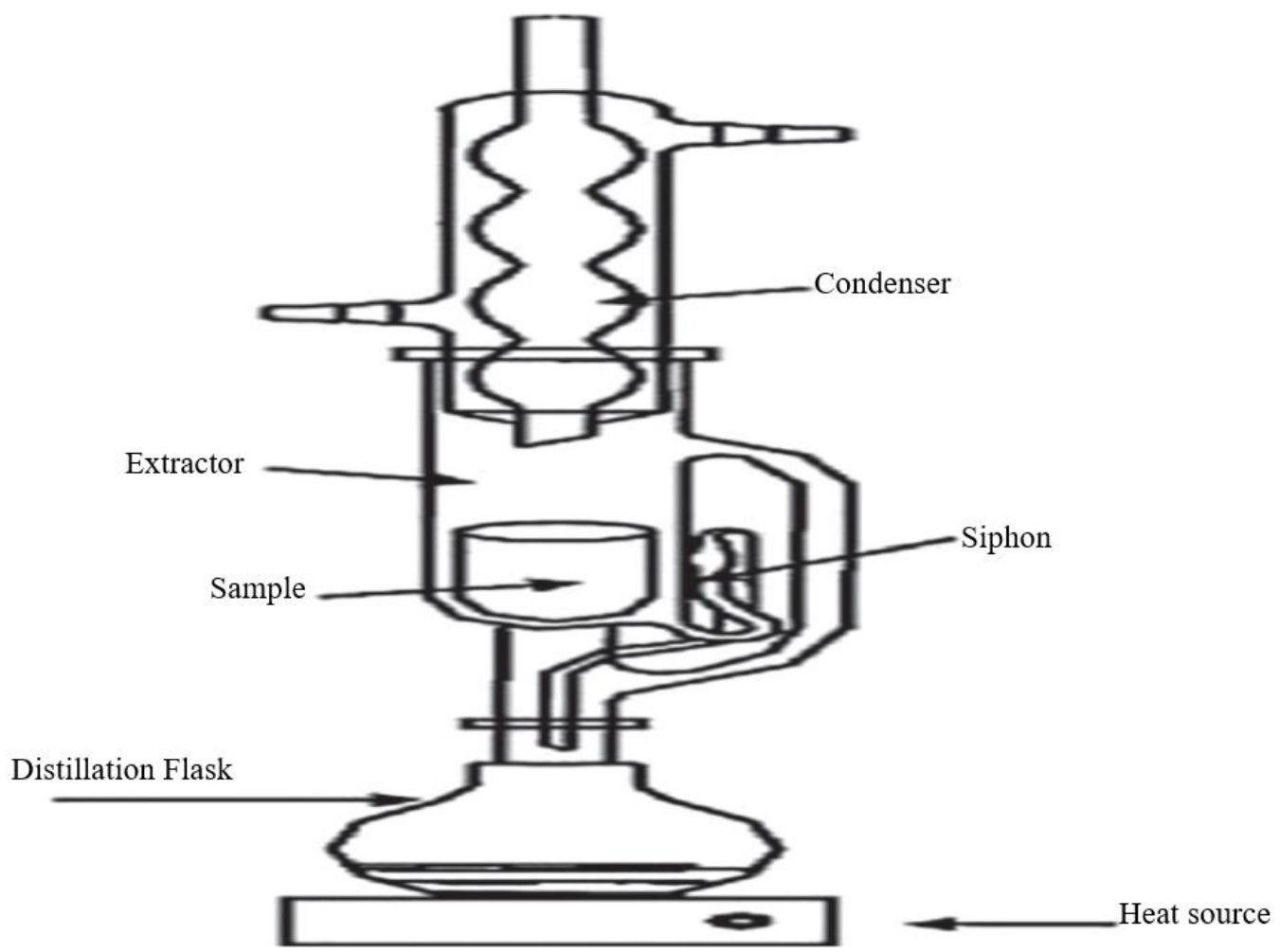

Fig. 1. Oil Extraction Set up using Soxhlet Extractor Determination of specific gravity 


\section{Determination of peroxide value}

A mass of $0.5 \mathrm{~g}$ of the sample was weighed into a conical flask. $25 \mathrm{ml}$ of solvent mixture was added, that is, 2 volume of glacial acetic acid and 1 volume of chloroform. $1 \mathrm{ml}$ of $10 \%$ potassium iodide was added and shaken vigorously. The solution was covered with a stopper and kept in the dark for 30 minutes. A volume $35 \mathrm{ml}$ of starch indicator was added, and titrated $\left(\mathrm{V}_{1}\right)$ with $0.02 \mathrm{M}$ sodium thiosulphate until solution turned colorless. The blank was done starting with $25 \mathrm{ml}$ of solvent mixture and volume $\mathrm{V}_{2}$ sodium thiosulphate to titrate the blank was recorded. The peroxide values of the oil samples were then determined using equation (3).

$$
\text { Peroxide Value }=\frac{(V 2-V 1)}{\text { Weight of sample }} \times C
$$

Where:

$\mathrm{C}=$ Concentration of sodium thiosulphate used.

\section{Determination of the free fatty acid}

Diethyl ether $(1: 1 \mathrm{v} / \mathrm{v})$ mixture and $2 \mathrm{ml}$ of $1 \%$ phenolphthalein solution was added to $20 \mathrm{ml}$ of ethanol and the mixture was neutralized using $0.10 \mathrm{M} \mathrm{NaOH}$ solution. Then $5 \mathrm{~g}$ of oil sample was added to the neutralized mixture and titrated against $0.10 \mathrm{M} \mathrm{NaOH}$ solution with constant shaking until a pink color developed and persisted for 15 minutes. The titre values were used to obtain the free fatty acid values using equation (4).

$$
F F A=\frac{\text { titre value } \times \mathrm{M} \times 5.61}{\text { weight of oil sample used }}
$$

\section{Determination of iodine value}

A mass of $0.5 \mathrm{~g}$ of the oil was put into a conical flask. A $15 \mathrm{ml}$ volume of chloroform was added after which $25 \mathrm{ml}$ of wiji's solution was added and covered tightly using a sheet of foil and kept in the dark for 30 minutes. Thereafter, $20 \mathrm{ml}$ of $10 \%$ potassium iodide was added followed by $150 \mathrm{ml}$ of distilled water, at that point the color changed from brown to wine red. A volume of $5 \mathrm{ml}$ of $1 \%$ starch indicator was added which turned the solution blue black. The whole solution was titrated with $0.1 \mathrm{~N}$ sodium thiosulphate till immediately the end point is achieved and volume $\mathrm{V}_{1}$ of sodium thiosulphate to turn the solution from blue black to colorless is recorded. The blank was carried out as well starting with $15 \mathrm{ml}$ of chloroform and the volume of sodium thiosulphate, $\mathrm{V}_{2}$ for the blank also recorded. Equation (5) was then used to determine the iodine value of each oil sample.

$$
\text { Iodine value }=\frac{12.69 \times(\mathrm{V} 1-\mathrm{V} 2) \times \mathrm{C}}{\text { Weight of sample used }}
$$

Where:

$\mathrm{C}=$ sodium thiosulphate concentration.

\section{Determination of density}

Density bottle was used to determine the density of the oil. A clean and dry bottle of $25 \mathrm{ml}$ capacity was weighed as $\mathrm{W}_{1}$. It was then filled with the oil, stopper inserted and reweighed to give $\mathrm{W}_{2}$. The oil was substituted with water after washing and drying the bottle and weighed to give $\mathrm{W}_{3}$ as weight of density bottle and water. The specific gravities of the oil samples were then calculated using equation (6).

$$
\text { Specific gravity }=\frac{(\mathrm{W} 2-\mathrm{W} 1)}{(\mathrm{W} 3-\mathrm{W} 1)}=\frac{\text { Mass of the substance }}{\text { Mass of an equal volume of } \text { water }}
$$




\section{Determination of refractive index}

A refractometer was used in this determination. Few drops of the sample were transferred into the glass slide of the refractometer. Water at $30{ }^{\circ} \mathrm{C}$ was circulated round the glass slide to keep its temperature uniform. Through the eyepiece of the refractometer, the dark portion viewed was adjusted to be in line with the intersection of the cross. At no parallax error, the pointer on the scale pointed to the refractive index. This was repeated and the mean value noted and recorded as the refractive index.

\section{Determination of $\mathrm{pH}$ value}

The $\mathrm{pH}$ electrode was lowered into a buffer solution for the standardization of the $\mathrm{pH}$ meter. The calibrated control was adjusted and the meter indicated the exact $\mathrm{pH}$. The electrode was rinsed with water and then with a portion of the sample oil and then immersed into a $2 \mathrm{~g}$ of the oil sample which was contained in a clean $25 \mathrm{ml}$ beaker for about 3 minutes, the $\mathrm{pH}$ value was read and recorded.

\section{Determination of saponification value}

A mass of $0.5 \mathrm{~g}$ oil was poured into a conical flask. $50 \mathrm{ml}$ of $0.5 \mathrm{~N}$ alcoholic solution of $\mathrm{KOH}$ was added and the solution was refluxed for 30 minutes to ensure perfect dissolution. The solution was allowed to cool and 3 drops of phenolphthalein was added. The solution was titrated with $0.5 \mathrm{~N} \mathrm{HCl}$ and the point where the pink solution turned colorless was recorded as titre value $\mathrm{V}_{1}$. A similar procedure was done for the blank without adding the oil sample and the titre value recorded as $V_{2}$. Equation (7) was used in calculating saponification values of the oil samples.

$$
\text { Saponification value }=\frac{56.1 \times 0.5 \times(V 2-V 1)}{\text { weight of the sample used }}
$$

\section{Results and Discussion}

Fig. 2 shows the plots of the results of oil yields of neem and yellow oleander seeds and the free fatty acid content of the oils while the raw results are in Table 1 . The oil yields of neem $(38.80 \%)$ and yellow oleander $(49.69 \%)$ satisfy the percentage oil content $(30-55 \%)$ needed in vegetable seeds for biodiesel production as reported by [18]. [19], also reported an oil yield range of 25 to $45 \%$ for neem kernel. The results indicate that both seed samples used in this study possess oils yields required for commercial scale production of biodiesel. It can be seen from the results that yellow oleander seeds contain more oil than neem seeds. Soil conditions, the differences in biotype of plants, cultivation climates, ripening stages and the harvesting times of the seeds play significant roles in causing variations in oil yield [20,21]. According to [22], wrong seed processing such as leaving seeds to direct sunlight for a long period of time can also reduce the oil yield. In a study, [21] also reported that the oil content may be affected by the soil type and amount of rainfall.

Table 1. Oil yield of seeds and Fatty acid contents of Neem and Yellow oleander crude oils

\begin{tabular}{lll}
\hline Parameter & Neem & Yellow oleander \\
Oil yield \% & 38.80 & 49.69 \\
Free Fatty acid content $\%$ & 8.77 & 7.21 \\
\hline
\end{tabular}

The plots of results of the free fatty acid levels for the two samples are also shown on Fig. 2. The results show that both oil samples contain high free fatty acid values, $8.77 \%$ for neem and $7.21 \%$ for yellow oleander, as such direct alkaline transesterification will lead to the formation of soap resulting in low biodiesel production [6]. For maximum biodiesel yield, acid esterification of the oil must, therefore, be carried out to reduce high acid value to $2 \%$ or less prior to alkaline transesterification. This, however, will in the long run increase the cost of production. 
In Table 2 are the results the physical properties of the extracted oils while Fig. 3 shows the plot of the results. The oils are liquids at room temperature, golden yellow in color, and their odors agreeable and generally not offensive. The odor for neem seed oil is, however, a little pungent similar to the combined odors of garlic and peanut. A report by [23] indicated that the presence of many triterpenoids in the oil are responsible for the disagreeble odor. The specific gravities of neem $\left(0.87 \mathrm{~g} / \mathrm{cm}^{3}\right)$ and yellow oleander $\left(0.916 \mathrm{~g} / \mathrm{cm}^{3}\right)$ show that water is denser than both oils which specific gravities are within the range of 0.717 to $0.921 \mathrm{~g} / \mathrm{cm}^{3}$ as reported by [24]. Also, the values seem to indicate that no heavy element is present in the oils as reported by [25].

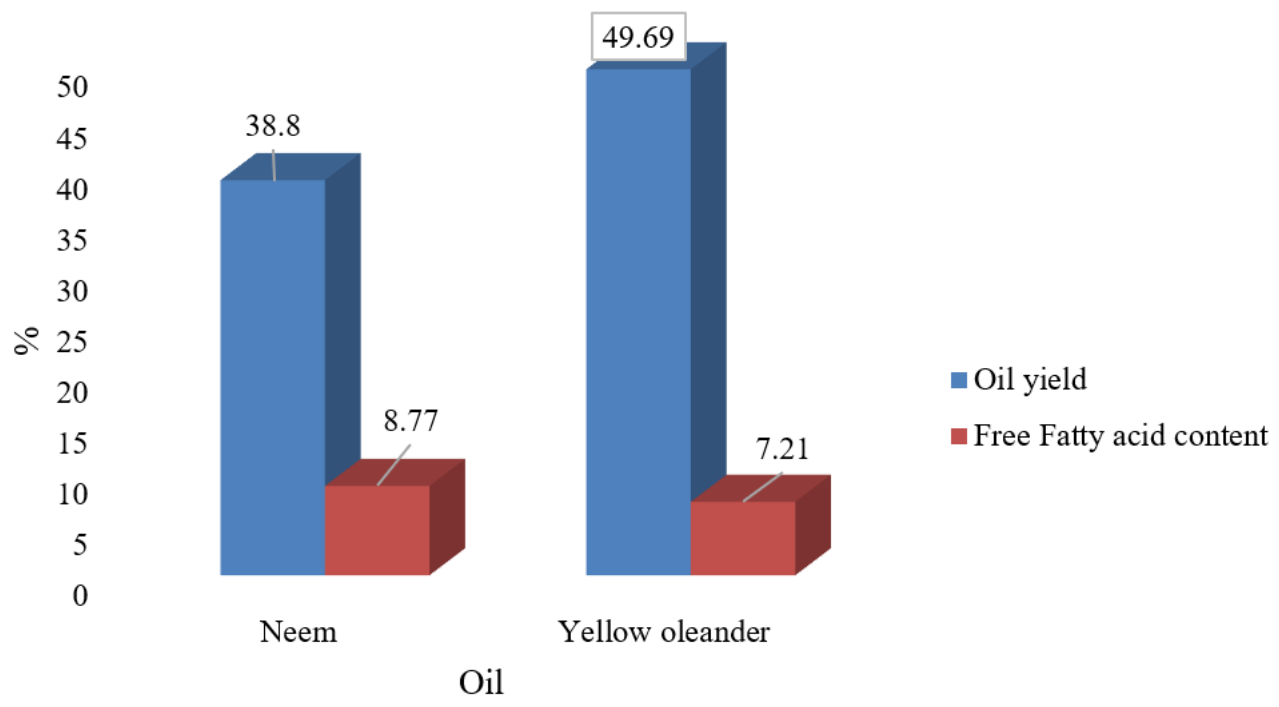

Fig. 2. Oil yields and free fatty acid contents of neem and yellow oleander seeds

Table 2. Physical properties of Neem and Yellow oleander crude oils

\begin{tabular}{lcc}
\hline & Neem seed oil & Yellow oleander seed oil \\
\hline Specific gravity $\left(\mathrm{g} / \mathrm{cm}^{3}\right)$ & 0.873 & 0.964 \\
Viscosity at $40{ }^{\circ} \mathrm{C}\left(\mathrm{mm}^{2} / \mathrm{s}\right)$ & 37.80 & 31.40 \\
Refractive index & 1.53 & 0.94 \\
$\mathrm{pH}$ & 6.1 & 5.9 \\
Colour & Golden yellow & Golden yellow \\
\hline
\end{tabular}

Results of refractive index analysis, (neem seed oil 1.469 and yellow oleander seed oil 1.467) are similar for both seed oils with only $0.14 \%$. These results satisfy ASTM standards values of 1.476 to 1.479 (ASTM, D960-52). It can be seen that the differences are insignificant and within acceptable experimental error ranges. Also, [26] reported a similar result (1.471). Thus, the refractive index of both neem and yellow oleander oils can be said to be in agreement with ASTM specification. The values also fall within the standard value for refractive index of organic oils which is between 1.3 and 1.6 [27]. Both seed oils can be said to be less susceptible to rancidity and may not spoil due to oxidation [28].

The $\mathrm{pH}$ values of the neem and yellow oleander seed oils are 5.9 and 6.11 respectively. The relatively low $\mathrm{pH}$ value obtained in this study for both oils is an indication of the presence of reasonably high amounts of free fatty acid and that neem oil has more FFA than yellow oleander oil. Acid esterification process must be carried out to reduce the FFA before transesterification for conversion into biodiesel to avoid low yields due to the formation of soaps.

The value of viscosities at $40{ }^{\circ} \mathrm{C}$ of the seed oils obtained are $37.80 \mathrm{~mm}^{2} / \mathrm{s}$ for neem and $31.40 \mathrm{~mm}^{2} / \mathrm{s}$ for yellow oleander. The value for yellow oleander seed oil compares favorably with 
those obtained for rape seed oil $\left(31.3 \mathrm{~mm}^{2} / \mathrm{s}\right)$, coconut oil $\left(34.9 \mathrm{~mm}^{2} / \mathrm{s}\right)$ and corn oil $\left(33.5 \mathrm{~mm}^{2} / \mathrm{s}\right)$ reported by [26] in their work. The used of fuels with high viscosity in engines block the fuel injection system and results in poor fuel atomization [29, 30]. Crude seed oils must therefore undergo transesterification to reduce their viscosities to avoid damages to the fuel injection system of the engines.

The plot of the chemical property characteristics of the extracted oils are presented in Fig. 4 while the raw values are in Table 3 . The saponification value for neem oil $(185.8 \mathrm{mg} \mathrm{KOH} / \mathrm{g}$ of oil) is lower when compared with the value of 190 to $194 \mathrm{mg} \mathrm{KOH} / \mathrm{g}$ of oil reported by [20] but within the standard of 175 to $205 \mathrm{mg} \mathrm{KOH} / \mathrm{g}$ of oil reported by [25]. Yellow oleander oil with the value of $196.3 \mathrm{mg} \mathrm{KOH} / \mathrm{g}$ of oil satisfies the standard reported by both [23, 27]. The results confirmed that seed oils of neem and yellow oleander have qualities required for use as raw materials in biodiesel industries. Oils with high saponification values can only be used in cosmetics, candle and soap making industries [28].

Table 3. Chemical properties of Neem and Yellow oleander crude oils

\begin{tabular}{lcc}
\hline \multicolumn{1}{c}{ Property } & Neem seed oil & Yellow oleander seed oil \\
\hline Acid value $(\mathrm{mg} \mathrm{KOH} / \mathrm{g}$ of oil) & 17.54 & 14.42 \\
Saponification value $(\mathrm{mg} \mathrm{KOH} / \mathrm{g}$ of oil) & 185.8 & 196.3 \\
Iodine value $(\mathrm{gI} / 100 \mathrm{~g})$ & 58 & 81 \\
Peroxide value $\left(\mathrm{meqO}_{2} / \mathrm{g}\right)$ & 7.95 & 4.20 \\
\hline
\end{tabular}

The acid values of the seed oils of neem and yellow oleander are high and fall outside the ASTM D6751 range of 0.4 to $4 \mathrm{mg} \mathrm{KOH} / \mathrm{g}$ with the value obtained for neem oil $(17.54 \mathrm{mg}$ $\mathrm{KOH} / \mathrm{g}$ ) significantly higher than that of yellow oleander oil which value is $14.42 \mathrm{mg} \mathrm{KOH} / \mathrm{g}$. According to [15], lower the acid values of oil, results in lower the fatty acids which makes it resistant rancidity. High acid values slow down biodiesel production reaction resulting in low yield and high cost of production.

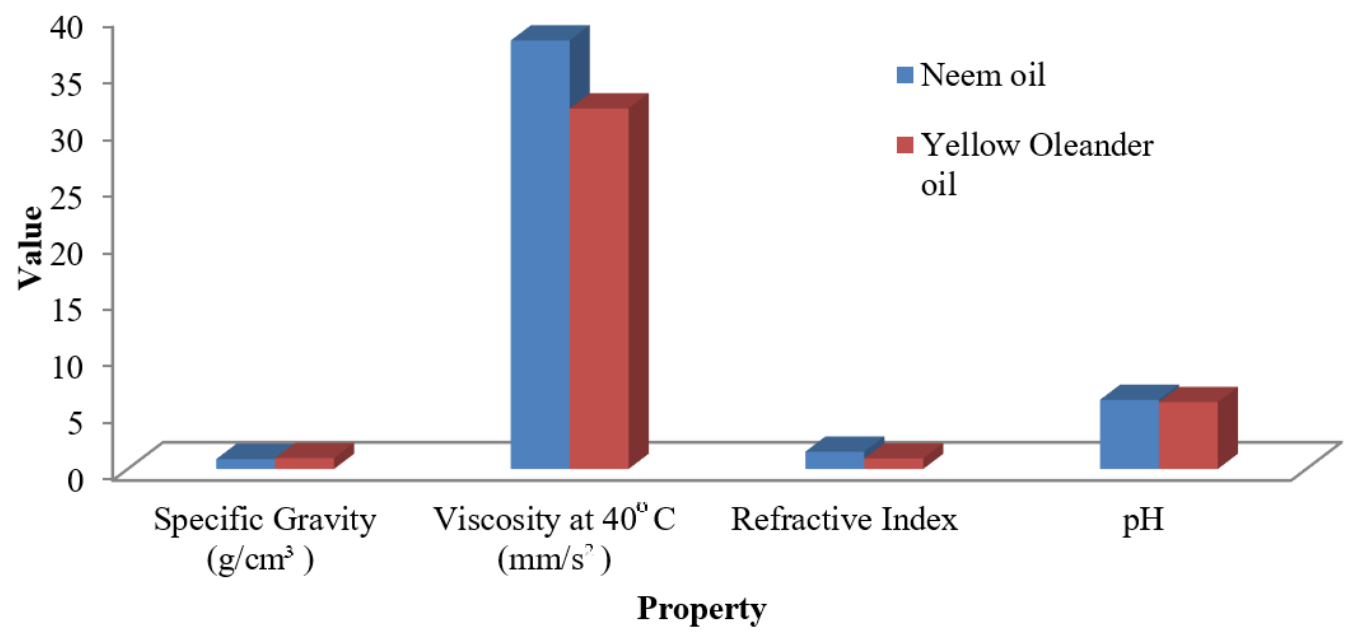

Fig. 3. Physical Properties of Neem and Yellow Oleander Seed Oils

In a similar study, [31] also reported that low acid value is an indication of the ability of oil to resist hypolitic hydrolysis and deterioration due to oxidation. This means that oils of the two seed samples used are exposed to rancidity because of the relatively high values of their acid values. It is easier for neem seed oil to become rancid than yellow oleander seed oil because of its higher acid content. The high acid values are due to high FFA in the seed oil. 
The iodine value of neem seed oil (58 mg iodine $/ \mathrm{g}$ ) is lower than the value of $60.72 \mathrm{mg}$ iodine $/ \mathrm{g}$ reported by [26] and $81 \mathrm{mg}$ iodine/g for yellow oleander seed oil. Both seed oil samples, however, have iodine values lower than the maximum value of 105 reported by [23]. Oil with iodine value less than 100 means that it is non-drying [31]. Both neem and yellow oleander seed oils are therefore nondrying and are also useful feedstocks for the production of lubricants and hydraulic brake fluids apart from biodiesel. According to [17, 29], high the iodine value results in unsaturation and lower viscosity, which consequently reflects the reactivity of the oil and makes it, becomes more susceptible to oxidation and rancidification. The implication of the result is that yellow oleander seed oil is a better source of raw material for biodiesel production than neem seed oil.

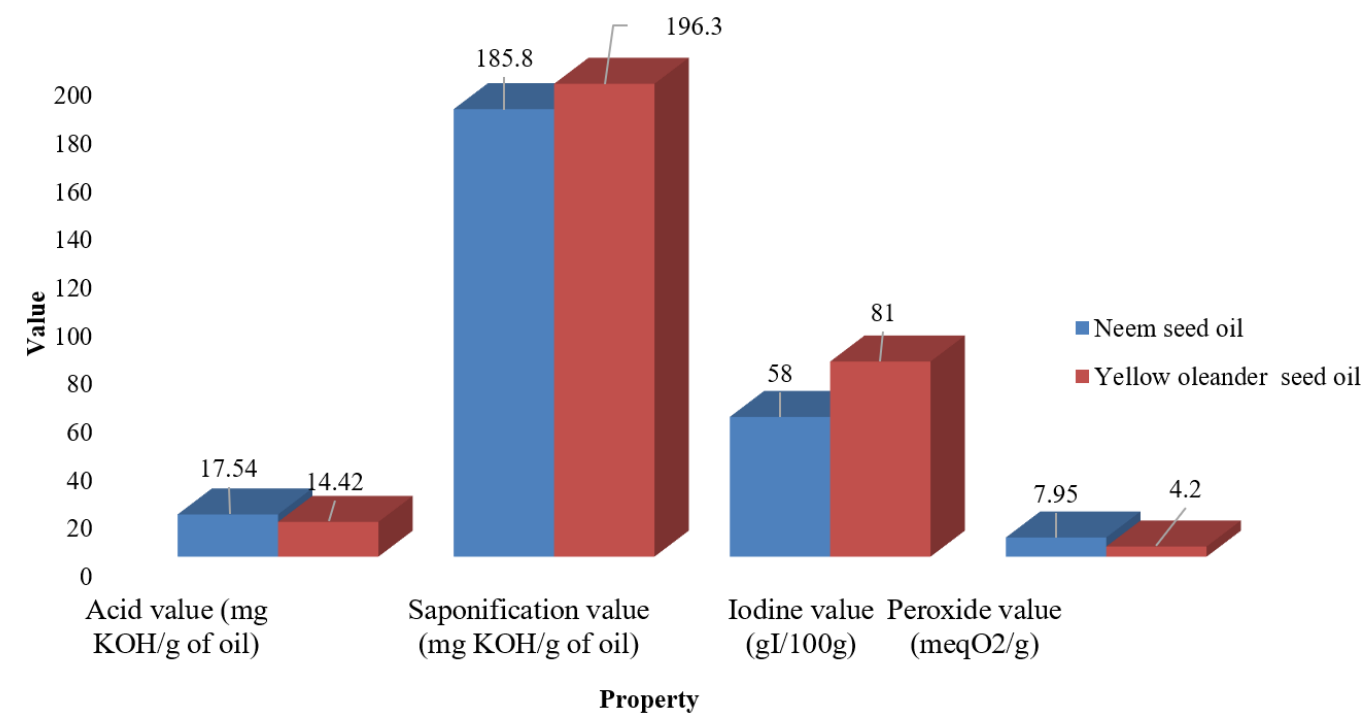

Fig. 4. Chemical Properties of Neem and Yellow Oleander Seed Oils

Peroxide value is an index of rancidity of oils. According to [31, 32], peroxide values higher than 9 meq $\mathrm{O}_{2} / \mathrm{g}$ indicate oxidation corruption in the seed oil. The result gotten in the case of neem is 7.95 meq $\mathrm{O}_{2} / \mathrm{g}$ while that of yellow oleander seed oil is $4.20 \mathrm{meq} \mathrm{O}_{2} / \mathrm{g}$. Both results are lower than that of sunflower oil (12.87) and linseed oil (11.28) as reported by [32] but higher than that of Lannea kerstingii seed oil as reported by [26]. The results show that the two seed oils can be stored for a long time without deterioration [32]. It further reveals that the oils are slow to polymerization and will remain liquid for long time [31].

\section{Conclusion}

The results of the experimental analyses carried out in this study indicate that neem and yellow oleander seeds are high-yielding and good sources of oil for commercial biodiesel production. Values obtained for physico chemical properties of the extracted oils fall within the acceptable limits for oils suitable for biodiesel production by international standards.

\section{Acknowledgement}

We wish to thank the following technical staff of Department of microbiology, for their technical assistances in their various laboratories during the extraction of seed oils: Adegoke A. Paul, Fatima Hamza and Umaru U. Ngamlamu. We are also grateful to Aliyu S. Usman of Chemistry Department for his assistance in the characterization of the oils. 


\section{References}

[1] S. Dworakowska, S, Bednarz, D. Bogdal. Production of biodiesel from rapeseed oil. $\mathbf{1}^{\text {st }}$ world sustainability forum, November, $\mathbf{1 - 3 0}^{\text {th }}, 2011$, pp. 1-6.

[2] D. Rutz, R. Janssen. Biofuel technology handbook. WIP renewable energies Sylvensteinstr. 2 81369, München Germany, 2, D5, 2008, pp. 38.

[3] Atabani, A. S. Silitonga, I. A. Badruddin, T. M. T. Mahlia, H .H. Masjuki, A. S. Mekhilef. A comprehensive review on biodiesel as an alternative energy source and its characteristics. Renewable Sustainable Energy review, 16(4), 2012, pp. 2070-2093.

[4] Demirbas. Progress and recent trends in biodiesel fuels. Energy conversion and management, 50(1), 2009, pp. 14-34.

[5] G. Kafuku, M. Mbarawa. Influence of fatty acids profiles during supercritical transesterification of conventional and non conventional feedstocks: A review. American Journal of analytical chemistry, 4, 2013, pp. 469-475.

[6] M. Ogbu, V. I. E. Ajiwe. Biodiesel production via esterification of free fatty acids from Cucurbita pepo L. Seed Oil: Kinetic Studies. International journal of science and technology, 2(8), 2013, pp. 616-621.

[7] K. M. Shereena, T. Thangaraj. Biodiesel: An alternative fuel Produced from vegetable oils by transesterification. Electronic journal of biology, 5(3), 2009, pp. 67-74.

[8] K. A. Zahan, M. Kano.Biodiesel production from palm oil, its bye-products and Mill effluent: A review. Energies,11, 2132, 2018, pp. 1-25.

[9] S .N. Gebremariam, J. M. Marchetti. Biodiesel production technologies: review. AIMS Energy 5(3), 2017, pp. 425-457.

[10] H.S.G. Sidra, T. Mahmood, U. Nawaz. Biodiesel production by using $\mathrm{CaO}-\mathrm{Al}_{2} \mathrm{O}_{3} \mathrm{Nano}$ catalyst. Int J Eng Res Sci 2, 2016, pp.2395- 6992.

[11] Pal, R. K. Singh, S. Mohan. Biodiesel conversion of high FFA Neem oil by blending it with low FFA sesame oil. Journal of scientific and innovative research, 4(3), 2015, pp. 127-130.

[12] World Energy Council. Biofuels: Policies, Standards and Technologies. World Energy Council, regency house 1-4 Warwick street London W1B5LT United Kingdom, 2010, pp. 23- 24.

[13] M. Balat. Potential alternatives to edible oils for biodiesel production: A review of current work. Energy conversion and management, 5, 2011, pp. 21479-1482.

[14] M. M. K. Bhuiya, M. G. Rasul, M. M. K. Khan, N. Ashwat, A.K. Azad. Second generation biodiesel: Potential alternative to edible oil-derived biodiesel. The Sixth International conference on Applied energy- ICAE2014. Energy procedia, 61, 2014, pp.1969-1972.

[15] O. W. J. O. Eze, I. N. Olivia. Extraction and characterization of oil from melon and coconut seeds. International journal of pharmaceutical science invention, 6(9), 2017, pp. 09-12.

[16] K. H. Ijeoma, U. I. Prisca. Characterization of the chemical properties of some selected refined vegetable oils commonly sold in Nigeria. British journal of applied science and technology, 5(6), 2015, pp. 538-546.

[17] AOCS. AOCS official method Aa 4-38 reapproved 1997 revised 2001: oil. In Official Methods and Recommended Practices of the AOCS (5th edition). American Oil Chemists' Society Press, Champaign, IL. 2001.

[18] M. Ndana, Garba, B. Ndana, L. G. Hassan, U. Z. Faruk. Evaluation of physico chemical properties of biodiesel produced from some vegetable oils of Nigeria origin. Bayero Journal of Pure and Applied Sciences, 4(1), 2011, pp. 67 - 71.

[19] Y. G. Keneni, J. M. Marchetti. Oil extraction from plant seeds for biodiesel production. AIMS Energy, 5(2), 2017, pp. 316-340. 
[20] P. Bhandare, G. R. Naik. Biophysiochemical evaluation and micropropagation studies on Neem for biodiesel production. International journal of applied biology and pharmaceutical technology, 6(1), 2015, pp. 213- 222.

[21] J. G. Usman, P. C. Okonkwo, M. S. Shehu. Investigation into the usage of solvent for extracting Neem oil from Neem seed for industrial application. Academic journal of interdisciplinary studies MCSER publishing, Rome-Italy, 3(5), 2014, pp. 39- 46.

[22] Raja, S. A, Robinson smart, D. S. and Lee, C. L. R. Biodiesel production from jatropha oil and its characterization. Research Journal of chemical sciences, 1(1), 2011, pp. 81-87.

[23] S. G. Zaku, S. A. Emmanuel, A. H. Isa, A. Kabir. Comparative studies on the functional properties of Neem, Jatropha, Castor and Moringa seed oils as potential feedstock for biodiesel production in Nigeria. Global journal of science frontier research chemistry, 12(7), version 1.0, 2012, pp. 23-26.

[24] W. Parawira. Biodiesel production from Jatropha curcas: A review. Scientific research and essays, 5(14), 2010, pp.1796-1808.

[25] T. Sathya, A. Manivannan. Biodiesel production from neem oil using two step transesterification. International journal of engineering research and application, 13(3), 2013, pp. 488-492.

[26] J. T. Quilly, P. Bazongo, A. Bougma, N. Kabore, A. M. Lykke, A. Quedraogo, I. H. N. Bassole. Chemical composition, physiochemical characteristics and nutritional value of lannea kerstingii seeds and seed oil. Hindawi journal of analytical methods in chemistry, 2017, pp. 1-6.

[27] J. E. Asuquo, E. E. Etim, I. U. Ukpong, S. E. Ukpong. Extraction, characterization and fatty acid profile of Poga oleosa oil. International journal of modern analytical and separation sciences, 1(1), 2012, 23-30.

[28] Sarkar, J. P. Pandey, A. Singh, L. Tiwari, A. Kumar. A novel method of using refractive index as tool for finding the quality of aqueous enzymatic extracted algae oil. Pelagia research library. Advances in applied science research, 6(4), 2015, pp. 50- 60.

[29] N. Usta, B. Aydog an, A. H. Çon, E. S. Ug־uzdog an, and G. Özkal. Properties and quality verification of biodiesel produced from tobacco seed oil. Energy conversion and management, 52, 2011, pp. 2031-2039.

[30] M. M. Aji, B. Gutti, B. K. Highina, S. A. Kyari. Soxhlet extraction and characterization of oil from Canarium schweinfurthii (black date) fruits for domestic purposes. Applied research journal, 1(2), 2015. pp. 41-45.

[31] E.O. Okene, B. O. Evbuomwan. Solvent Extraction and Characterization of Oil from Coconut Seed Using Alternative Solvents. International Journal of Engineering and Technical Research, 2(12), 2014, pp. 45-51.

[32] Z. Amri, H L Aref, M. Mekni, S. El-Gharbi, O. Dabbaghi, B. Mechri and M. Hammani. Oil composition and lipid class composition of Pomegranate seeds. Hindawi journal of biomed research international, 2017 pp. 1-8.

Received: July 04, 2020

Accepted: September 29, 2020 